partial loss of this terminal $-\mathrm{CH}_{3}$ group. (5) Finally, in the region above $8 \cdot 5 \mu$, the bands at $11 \cdot 15,12 \cdot 50$ and $13 \cdot 85 \mu$ (Fig. 2) appear to be characteristic for both crude and purified cryptococeal polysaccharides.

H. H. Gadebusch

General Medical Research Section,

Veterans Administration Hospital, Ann Arbor, Michigan.

${ }^{1}$ Levine, S., Stevenson, H. J. R., and Kabler, P. W., Arch. Biochem., 45,65 (1953).

Watson, R. G., Marinetti, G. V., and Scherp, H. W., J. Immunol., 81, $337(1958)$

Neill, J. M., Castillo, G. G., Smith, R. H., and Kapros, C. E., J. Exp Med., 89, $93(1949)$

4 Evans, E. E., and Kessel, J. F., J. Immunol., 67, 109 (1951).

${ }^{5}$ Gadebusch, H. H., J. Infect. Dis., 102, 219 (1958).

'Sevag, M. G., Lackman, D. B., and Smolens, J., J. Biol. Chem. 124,425 (1938).

' Evans, E. E., Proc. Soc. Exp. Biol. Med., 71, 644 (1949).

s Stevenson, H. J. R., and Levine, S., Science, 116, 705 (1952),

\section{Carnitine in Lipid Metabolism}

THE finding by Fraenkel and Friedman ${ }^{1}$ that carnitine (4-trimethyl amino 3 hydroxy butyric acid) is an essential growth factor for certain organisms (vitamin $\mathrm{B}_{\mathrm{T}}$ ) and its availability by synthesis have renewed interest in the problem of its biochemical function.

Recent reports suggest that carnitine is implicated in lipid metabolism. Schaepdryver and Vleeschhouwer ${ }^{2}$ showed that it increased the fat content of lymph; Fritz and McEwan ${ }^{3}$ postulated a role in fat transport; and it has been reported present in vagotonin $^{4}$ and lipocaic ${ }^{5}$. Binon and Deltour ${ }^{6}$ reported that, contrary to the belief that the nitrogenous base of $\operatorname{dog}$ serum phospholipid was all choline, one-third was actually carnitine.

The chemical similarity of carnitine and choline suggests that carnitine might possess anti-lipotropic activity. This possibility was examined by the 6 -day mouse test of Welch and Welch? Seventy young male mice were fed on $(a)$ high fat, negative control diet; (b) positive controls containing 0.5 per cent choline; (c) test diet containing 0.5 per cent carnitine; and $(d)$ test diet containing 1.0 per cent carnitine. The results (Table 1) show that carnitine had no effect on the fat content of the liver. This result substantiates the finding of $\mathbf{F r i t z}^{8}$ on rats.

As a further exarnination of the role of carnitine in lipid metabolism the finding of Binon and Deltour ${ }^{6}$ was investigated. These authors analysed the total lipid fraction from dog serum by differential reineckate precipitation ${ }^{9}$. The precipitate at $p H 10$ was assumed to be choline, and that at $p \mathrm{H} 2$, carnitine. The carnitine was not further identified.

Table 1. Total Lipid Content of Mouse Lrvars (Four ANmals GROUPED IN EACH DETERMINATION)

\begin{tabular}{|c|c|c|c|c|}
\hline Group & $\begin{array}{l}\text { High diet fat. } \\
\text { Negative controls } \\
\text { (choline + carn- } \\
\text { itine absent) } \\
\text { (gm. } / 100 \mathrm{gm} .)\end{array}$ & $\begin{array}{l}\text { Plus } 0.5 \text { per } \\
\text { cent choline. } \\
\text { Positive } \\
\text { controls } \\
\text { (gm./100 gm.) }\end{array}$ & $\begin{array}{l}\text { Plus } 0.5 \\
\text { per cent } \\
\text { carnitine } \\
\text { (gm./ } \\
100 \mathrm{gm} .)\end{array}$ & $\begin{array}{l}\text { Plus 1.0 } \\
\text { per cent } \\
\text { carnitine } \\
\text { (gm./ } \\
100 \mathrm{gm} .)\end{array}$ \\
\hline $\begin{array}{c}\text { Total } \\
\text { animals } \\
\text { used } \\
1 \\
2 \\
3 \\
4 \\
5\end{array}$ & $\begin{array}{l}54 \cdot 2 \\
55 \cdot 4 \\
52 \cdot 2 \\
59 \cdot 0 \\
60 \cdot 7\end{array}$ & $\begin{array}{l}10 \cdot 9 \\
12 \cdot 4 \\
19 \cdot 9 \\
11 \cdot 2 \\
22 \cdot 5\end{array}$ & $\begin{array}{l}58 \cdot 6 \\
55 \cdot 0 \\
55 \cdot 4 \\
51 \cdot 3 \\
53 \cdot 0\end{array}$ & $\begin{array}{c}10 \\
\text { (2 per } \\
\text { group) } \\
58 \cdot 5 \\
57 \cdot 2 \\
47 \cdot 5 \\
47 \cdot 1 \\
62 \cdot 1\end{array}$ \\
\hline
\end{tabular}

The lipids from $300 \mathrm{ml}$. of foxhound serum were extracted with ethanol/ether and hydrolysed by boiling with methanolic hydrochloric acid (following the procedure of Binon and Deltour). The two fractions obtained by differential reineckate precipitation at $p \mathrm{H} 10$ (voluminous) and $p \mathrm{H} 2$ (trace) were examined by paper chromatography. They were run in the presence of silver nitrate ${ }^{10}$ in ethanol/ammonium hydroxide/water $(95: 5: 5)$ and in a second experiment in isopropanol/ammonium hydroxide/water $(20: 1: 2)$. The spots were located with iodine and with potassium bismuth iodide. Choline was the only quaternary ammonium compound detected in both reineckate fractions. Direct chromatography of the phospholipid hydrolysate, without reineckate treatment, also failed to reveal the presence of carnitine.

In addition to the serum investigation the phospholipid fraction of beef muscle was examined. The fraction was obtained by petroleum ether/ethanol extraction followed by acetone precipitation ${ }^{11}$. The hydrolysed material showed no reineckate precipitate under acid conditions, and chromatography revealed choline as the only quaternary ammonium compound.

It thus appears that carnitine is not present in phospholipids of blood or muscle, and that it does not play a part in transmethylation reactions that lead to the formation of choline or betaine.

A detailed account of this work and further investigations into the role of carnitine will be published elsewhere.

E. P. Adams

P. E. Ballance

A. E. Bender

Research Department, Bovril Ltd., P.O. Box 107,

148-166 Old Street, London, E.C.1.

1 Fraenkel, G., and Friedman, S., "Vitamins and Hormones", 15 (1957).

${ }^{2}$ Schaepdryver, A. F. de, and Vleeschhouwer, G. R. de, Arch. Intern. Pharmacodynamie, 113, 15 (1957).

${ }^{3}$ Fritz, I. B., and McEwan, B., Science, 129, 334 (1959).

4 Binon, F., and Deltour, G., Experientia, 12, 357 (1956).

- Binon, F., and Deltour, G., C.R. Soc. Biol., 149, 932 (1955).

- Binon, F., and Deltour, G., Rev. fermentations et indus. aliment. $11,14(1956)$

'Welch, M. S., and Welch, A. DeM., Proc. Soc. Exp. Biol. Med., 39, 5 (1938).

${ }^{8}$ Fritz, I. B., Amer. J. Physiol., 190, 449 (1957).

s Binon, F., Voeding, 16, 781 (1955).

${ }_{10}$ Bregoff, H. M., Roberts, E., and Delwiche, C. C., J. Biol. Chem., 205,565 (1953).

${ }^{11}$ Hardman, E. E., and Crombie, W. M. L., J. Exp. Bot., 9, 239 (1958).

\section{7-Oxosteroids of Pregnant Ewes' Urine}

IN view of the increasing use of steroid hormones and stilbene derivatives in agriculture and agricultural research, it was felt that it was necessary to investigate steroid excretion by the ewe.

The isolation of $5 \beta$-pregnane $-3 \alpha: 20 \alpha$-diol from the urine of the pregnant ewe was recently reported by Robertson and Coulson ${ }^{1}$. As a continuation of this work the neutral ketonic fraction of pregnant ewes' urine was investigated.

$22.5 \mathrm{l}$. of urine representing twenty $24 \cdot \mathrm{hr}$. collections from two ewes in the fourth month of pregnancy, were acid hydrolysed and extracted in the usual way. The neutral extract was separated into ketonic and non-ketonic fractions by the method of Dorfman². 